\title{
2020: The year a viral asteroid collided with planet earth
}

Finally, 2020 is coming to an end, but the agony its viral pandemic inflicted on the entire world population will continue for a long time. And much as we would like to forget its damaging effects, it will surely be etched into our brains for the rest of our lives. The children who suffered the pain of the coronavirus disease 2019 (COVID-19) pandemic will endure its emotional scars for the rest of the 21st century.

Reading about the plagues of the past doesn't come close to experiencing it and suffering through it. COVID19 will continue to have ripple effects on every aspect of life on this planet, on individuals and on societies all over the world, especially on the biopsychosocial well-being of billions of humans around the globe.

\section{Unprecedented disruptions}

Think of the unprecedented disruptions inflicted by the trauma of the COVID19 pandemic on our neural circuits. One of the wonders of the human brain is its continuous remodeling due to experiential neuroplasticity, and the formation of dendritic spines that immediately encode the memories of every experience. The turmoil of 2020 and its virulent pandemic will be forever etched into our collective brains, especially in our hippocampi and amygdalae. The impact on the developing brains of our children and grandchildren could be profound and may induce epigenetic changes that trigger psychopathology in the future..$^{1,2}$

As with the dinosaurs, the 2020 pandemic is like a "viral asteroid" that left devastation on our social fabric and psychological well-being in its wake. We now have deep empathy with our 1918 ancestors and their tribulations, although so far, in the United States the proportion of people infected with COVID-19 (3\% as of mid-November $\left.2020^{3}\right)$ is dwarfed by the proportion infected with the influenza virus a century ago $(30 \%)$. As of mid-November 2020, the number of global COVID-19 deaths (1.3 million $\left.{ }^{3}\right)$ was a tiny fraction of the 1918 influenza pandemic deaths (50 million worldwide and 675,000 in the United States ${ }^{4}$ ). Amazingly, researchers did not even know whether the killer germ was a virus or a bacterium until 1930, and it then took another 75 years to decode the genome of the influenza virus in 2005. In contrast, it took only a few short weeks to decode the genome of the virus that causes COVID-19 (severe acute respiratory syndrome-related coronavirus 2), and to begin developing multiple vaccines "at warp speed." No vaccine or therapies were ever developed for victims of the 1918 pandemic.

An abundance of articles has been published about the pandemic since it ambushed us early in 2020, including many in CurRent Psychiatry. ${ }^{5-21}$

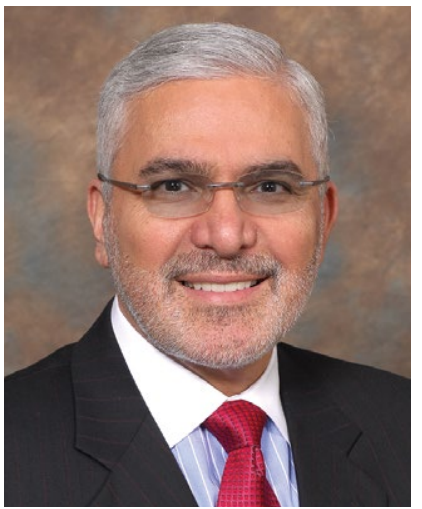

Henry A. Nasrallah, MD Editor-in-Chief doi: 10.12788/cp.0069

COVID-19 will continue to affect the biopsychosocial well-being of billions of humans around the globe
To comment on this editorial or other topics of interest:

henry.nasrallah

@currentpsychiatry.com 


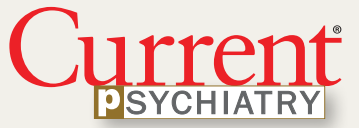

Editorial Staff

EDITOR Jeff Bauer

SENIOR EDITOR Sathya Achia Abraham ASSISTANT EDITOR Jason Orszt

WEB ASSISTANTS

Tyler Mundhenk, Kathryn Wighton

Art \& Production Staff

CREATIVE DIRECTOR Louise Koenig

ART DIRECTOR Pat Fopma

DIRECTOR, JOURNAL MANUFACTURING Michael Wendt

PRODUCTION MANAGER Donna Pituras

Publishing Staff

PUBLISHER Sharon Finch

DIRECTOR EBUSINESS DEVELOPMENT

Alison Paton

SENIOR DIRECTOR OF SALES

Tim LaPella

Editor-in-Chief Emeritus

James Randolph Hillard, MD

Frontline Medical Communications

VP, SALES Mike Guire

VP, DIGITAL CONTENT \& STRATEGY

Amy Pfeiffer

PRESIDENT, CUSTOM SOLUTIONS JoAnn Wahl

CIRCULATION DIRECTOR Jared Sonners

DIRECTOR, CUSTOM PROGRAMS

Patrick Finnegan

In affiliation with Global Academy for Medical Education, LLC

PRESIDENT David J. Small, MBA

\section{FRONTLINE MCedge}

7 Century Drive, Suite 302

Parsippany, NJ 07054

Tel: (973) 206-3434

Fax: (973) 206-9378

www.frontlinemedcom.com

Subscription Inquiries:

subscriptions@mdedge.com

Published through an

educational partnership with

léCINCINNATI
But these publications don't do justice to the emotional toll of living through the pandemic and witnessing its multifarious repercussions (Table, page 17). It was truly bizarre and shocking for us to see our society and all its components literally come to a standstill, forcing the population to stop working, reducing us to simply "existing" inside our homes, with no socializing, traveling, or interacting. More unbearable than the sudden emptiness and paralysis was the unremitting fear, laced with a profound uncertainty of what was to come or when it would end.

Most psychiatrists are familiar with the Holmes and Rahe Stress Scale, ${ }^{22}$ which contains 43 life events that cumulatively can progressively increase the odds of physical illness. It is likely that most of the world's population will score very high on the Holmes and Rahe Stress Scale, which would predict an increased risk of medical illness, even after the pandemic subsides.

Exacerbating the situation is that hospitals and clinics had to shut down most of their operations to focus their resources on treating patients with COVID-19 in ICUs. This halted all routine screenings for cancer and heart, kidney, liver, lung, or brain diseases. In addition, diagnostic or therapeutic procedures such as endoscopies, colonoscopies, angiograms, or biopsies abruptly stopped, resulting in a surge of non-COVID-19 medical disorders and mortality as reported in several articles across many specialties. ${ }^{23}$ Going forward, in addition to COVID-19 morbidity and mortality, there is a significant likelihood of an increase in myriad medical disorders. The COVID-19 pandemic is obviously inflicting both direct and indirect casualties as it stretches into the next year and perhaps longer. The only hope for the community of nations is the rapid arrival of evidence-based treatments and vaccine(s).

\section{A progression of relentless stress}

At the core of this pandemic is relentless stress. When it began in early 2020, the pandemic ignited an acute stress reaction due to the fear of death and the oddness of being isolated at home. Aggravating the acute stress was the realization that life as we knew it suddenly disappeared and all business or social activities had come to a screeching halt. It was almost surreal when streets usually bustling with human activity (such as Times Square in New York or Michigan Avenue in Chicago) became completely deserted and eerily silent. In addition, more stress was generated from watching television or scrolling through social media and being inundated with morbid and frightening news and updates about the number of individuals who became infected or died, and the official projections of tens of thousands or even hundreds of thousands of fatalities. Further intensifying the stress was hearing that there was a shortage of personal protective equipment (even masks), a lack of ventilators, and the absence of any medications to fight the overwhelming viral infection. Especially stressed were the front-line physicians and nurses, who heroically transcended their fears to save their patients' lives. The sight of refrigerated trucks serving as temporary morgues outside hospital doors was chilling. The world became a macabre place where people died in hospitals without any relative to hold their hands or comfort them, and then were buried quickly without any formal funerals due to mandatory social distancing. The inability of families to grieve for their loved ones added another poignant layer of sadness and 


\section{The multifaceted impacts of the COVID-19 pandemic}

\begin{tabular}{|c|c|}
\hline Category & Examples \\
\hline Infection-related & $\begin{array}{l}\text { Death, severe illness, quarantine, social distancing, masks, sanitizing } \\
\text { everything, frequent handwashing }\end{array}$ \\
\hline Neuropsychiatric & $\begin{array}{l}\text { Anxiety, depression, acute stress reaction, posttraumatic stress } \\
\text { disorder, cognitive impairment, headache, suicide, aggression } \\
\text { (towards children and partners), substance use and alcohol use } \\
\text { disorders, cognitive dysfunction, encephalopathy, anosmia, stroke, } \\
\text { headache, delirium, myalgia }\end{array}$ \\
\hline Economic & $\begin{array}{l}\text { Unemployment, poverty and hunger, evictions, business shutdowns, } \\
\text { bankruptcies, radical monetary policies, negative interest on savings, } \\
\text { huge government borrowing, stock market oscillations }\end{array}$ \\
\hline Education & Closure of schools, closure of colleges, switch to online learning \\
\hline $\begin{array}{l}\text { Suspension of } \\
\text { social functions }\end{array}$ & $\begin{array}{l}\text { No weddings, funerals, graduation ceremonies, sporting events, } \\
\text { concerts, shopping, eating at restaurants, drinking at bars, attending } \\
\text { religious gatherings, visiting relatives, hugging, kissing, or other } \\
\text { intimate activities }\end{array}$ \\
\hline Travel & $\begin{array}{l}\text { Collapse of the airline industry, collapse of the hotel industry, no } \\
\text { business travel, no vacations }\end{array}$ \\
\hline $\begin{array}{l}\text { Suspension of } \\
\text { routine health } \\
\text { care }\end{array}$ & $\begin{array}{l}\text { No visits to primary care physicians, no health screenings (cancer, } \\
\text { cardiac disease, diabetes, etc.), no medical procedures, huge drop in } \\
\text { emergency department visits, avoidance of dental care }\end{array}$ \\
\hline $\begin{array}{l}\text { Vulnerable } \\
\text { populations }\end{array}$ & $\begin{array}{l}\text { Higher mortality among older adults, minority patients, adults and } \\
\text { children with comorbid medical disorders, front-line physicians, nurses, } \\
\text { and technicians }\end{array}$ \\
\hline Political & $\begin{array}{l}\text { Social unrest, intensified partisanship, protests (against lockdowns or } \\
\text { the police), riots/looting, unprecedented political activities }\end{array}$ \\
\hline $\begin{array}{l}\text { Medical literature } \\
\text { and research }\end{array}$ & $\begin{array}{l}\text { Dominance of COVID-19 articles over other topics in major journals, } \\
\text { divergence of medical research to focus on developing COVID-19 } \\
\text { therapies, unprecedented acceleration of vaccine development } \\
\text { (perhaps at the expense of general medical research and development), } \\
\text { decline in enrollment in clinical trials }\end{array}$ \\
\hline $\begin{array}{l}\text { Demographic } \\
\text { impact }\end{array}$ & $\begin{array}{l}\text { Decline in pregnancies and birthrate; disproportionate mortality among } \\
\text { older adults and those with medical morbidities }\end{array}$ \\
\hline
\end{tabular}

distress to the survivors who were unable to bid their loved ones goodbye. This was a jarring example of adding insult to injury.

With the protraction of the exceptional changes imposed by the pandemic, the acute stress reaction transmuted into posttraumatic stress disorder (PTSD) on a wide scale. Millions of previously healthy individuals began to succumb to the symptoms of PTSD (irritability, hypervigilance, intrusive thoughts, avoidance, insomnia, and bad dreams). The heaviest burden was inflicted on our patients, across all ages, with preexisting psychiatric conditions, who comprise approximately $25 \%$ of the population per the classic Epidemiological Catchment Area (ECA) study. ${ }^{24}$ These vulnerable patients, whom we see in our clinics and hospitals every day, had a significant exacerbation of their psychopathology, including anxiety, depression, psychosis, binge eating disorder, obsessive-compulsive disorder, alcohol and substance use disorders, child abuse, and intimate partner violence. ${ }^{25,26}$ The saving grace was the rapid adoption of telepsychiatry,
With the protraction of the exceptional changes imposed by the pandemic, the acute stress reaction transmuted into PTSD 
If something good comes from this catastrophic social stress that hobbled the entire population, it would be the dilution of the stigma of mental illness which our psychiatric patients rapidly accepted. Many of them found it more convenient than dressing and driving and parking at the clinic. It also enabled psychiatrists to obtain useful collateral information from family members or partners.

If something good comes from this catastrophic social stress that emotionally hobbled the entire population, it would be the dilution of the stigma of mental illness because everyone has become more empathic due to their personal experience. Optimistically, this may also help expedite true health care parity for psychiatric brain disorders. And perhaps the government may see the need to train more psychiatrists and fund a higher number of residency stipends to all training programs.

\section{Quo vadis COVID-19?}

So, looking through the dense fog of the pandemic fatigue, what will 2021 bring us? Will waves of COVID-19 lead to pandemic exhaustion? Will the frayed public mental health care system be able to handle the surge of frayed nerves? Will social distancing intensify the widespread emotional disquietude? Will the children be able to manifest resilience and avoid disabling psychiatric disorders? Will the survivors of COVID-19 infections suffer from post-COVD-19 neuropsychiatric and other medical sequelae? Will efficacious therapies and vaccines emerge to blunt the spread of the virus? Will we all be able to gather in stadiums and arenas to enjoy sporting events, shows, and concerts? Will eating at our favorite restaurants become routine again? Will engaged couples be able to organize well-attended weddings and receptions? Will airplanes and hotels be fully booked again? Importantly, will all children and college students be able to resume their education in person and socialize ad lib? Will we be able to shed our masks and hug each other hello and goodbye? Will scientific journals and social media cover a wide array of topics again as before? Will the number of deaths dwindle to zero, and will we return to worrying mainly about the usual seasonal flu? Will everyone be able to leave home and go to work again?

I hope that the thick dust of this 2020 viral asteroid will settle in 2021, and that "normalcy" is eventually restored to our lives, allowing us to deal with other ongoing stresses such as social unrest and political hyperpartisanship.

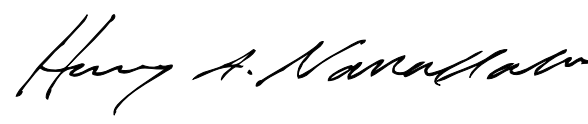

Henry A. Nasrallah, MD

Editor-in-Chief

References

1. Baumeister D, Akhtar R, Ciufolini S, et al. Childhood trauma and adulthood inflammation: a meta-analysis of peripheral C-reactive protein, interleukin- 6 and tumour necrosis factor- $\alpha$. Mol Psychiatry. 2016;21(5): 642-649.

2. Zatti C, Rosa V, Barros A, et al. Childhood trauma and suicide attempt: a meta-analysis of longitudinal studies from the last decade. Psychiatry Res. 2017; 256:353-358.

3. Johns Hopkins Coronavirus Resource Center. https://coronavirus.jhu.edu/. Accessed November 11,2020

4. Centers for Disease Control and Prevention. 1918 Pandemic. https://www.cdc.gov/flu/pandemicresources/1918-pandemic-h1n1.html. Accessed November 4, 2020.

5. Chepke C. Drive-up pharmacotherapy during the COVID-19 pandemic. Current Psychiatry. 2020; 19(5):29-30.

6. Sharma RA, Maheshwari S, Bronsther R. COVID-19 in the era of loneliness. Current Psychiatry. 2020; 19(5):31-33.

7. Joshi KG. Taking care of ourselves during the COVID-19 pandemic. Current Psychiatry. 2020;19(5): 46-47.

8. Frank B, Peterson T, Gupta S, et al. Telepsychiatry: what you need to know. Current Psychiatry. 2020; 19(6):16-23.

9. Chahal K. Neuropsychiatric manifestations of COVID-19. Current Psychiatry. 2020;19(6): 31-33

10. Arbuck D. Changes in patient behavior during COVID-19: what I've observed. Current Psychiatry. 2020;19(6):46-47.

11. Joshi KG. Telepsychiatry during COVID-19: understanding the rules. Current Psychiatry. 2020;19(6):e12-e14. 
12. Komrad MS. Medical ethics in the time of COVID-19. Current Psychiatry. 2020;19(7):29-32,46.

13. Brooks V. COVID-19's effects on emergency psychiatry. Current Psychiatry. 2020;19(7): 33-36,38-39.

14. Desarbo JR, DeSarbo L. Anorexia nervosa and COVID-19. Current Psychiatry. 2020;19(8):23-28.

15. Freudenreich O, Kontos N, Querques J. COVID-19 and patients with serious mental illness. Current Psychiatry. 2020;19(9):24-27,33-39.

16. Ryznar E. Evaluating patients' decision-making capacity during COVID-19. Current Psychiatry. 2020; 19(10):34-40.

17. Saeed SA, Hebishi K. The psychiatric consequences of COVID-19: 8 studies. Current Psychiatry. 2020; 19(11):22-24,28-30,32-35.

18. Lodhi S, Marett C. Using seclusion to prevent COVID-19 transmission on inpatient psychiatry units. Current Psychiatry. 2020;19(11):37-41,53.

19. Nasrallah HA. COVID-19 and the precipitous dismantlement of societal norms. Current Psychiatry. 2020;19(7):12-14,16-17.
20. Nasrallah HA. The cataclysmic COVID-19 pandemic: THIS CHANGES EVERYTHING! Current Psychiatry. 2020;19(5):7-8,16.

21. Nasrallah HA. During a viral pandemic, anxiety is endemic: the psychiatric aspects of COVID-19. Current Psychiatry. 2020;19(4):e3-e5.

22. Holmes TH, Rahe RH. The social readjustment rating scale. Journal of Psychosomatic Research 1967;11(2):213-218.

23. Berkwits $M$, Flanagin $A$, Bauchner $H$, et al. The COVID-19 pandemic and the JAMA Network. JAMA. 2020;324(12):1159-1160.

24. Robins LN, Regier DA, eds. Psychiatric disorders in America. The Epidemiologic Catchment Area study. New York, NY: The Free Press; 1991.

25. Meninger KA. Psychosis associated with influenza I. General data: statistical analysis. JAMA. 1919; 72(4):235-241.

26. Simon NM, Saxe GN, Marmar CR. Mental health disorders related to COVID-19-related deaths. JAMA 2020;324(15):1493-1494. 